\title{
Chemotherapy Induces Death Triangle Machinery Irreversibly, Reconsiderations on Different Cancer Treatments
}

\author{
Bahram Alamdary Badlou* \\ PhD Hematology, BBAdvies and Research, Research and Development Department, The Netherlands \\ *Corresponding author: Bahram Alamdary Badlou, PhD Hematology, BBAdvies and Research, Research and Development \\ Department, Zeist, The Netherlands
}

\begin{tabular}{|c|c|}
\hline ARTICLE INFO & ABSTRACT \\
\hline Received: May 06, 2019 & Citation: Bahram Alamdary Badlou. Chemotherapy Induces Death Triangle Machinery \\
\hline Published: 慧 May 13, 2019 & $\begin{array}{l}\text { Irreversibly, Reconsiderations on Different Cancer Treatments. Biomed J Sci \& Tech Res } \\
\text { 17(5)-2019. BJSTR. MS.ID.003078. }\end{array}$ \\
\hline
\end{tabular}

\section{Opinion}

Cancer affects health status of many subjects irreversibly and dramatically increases morbidity and mortality rate of the affected cancer patients [1-5]. Standard guidelines for cancer cure and care are mainly I. Surgery, II. Chemotherapy, III. Radiotherapy IV. Combination of $1+2 / 1+3 / 1+2+3$, and V. Alternative Medicine. All of these therapeutic approaches have own (dis-)advantages and cause (un-)known side effects which aggravates health status of patients toward end stage and risk of septic shock and death, eventually. Recent research studies in The Netherlands between 5 different Dutch Hospitals revealed compared to controls who did not get any chemotherapies, subjects who get chemotherapies with even modern chemicals did not show any significant progression toward health [4]. Recall, chemotherapy and radiotherapy induce apoptotic and necrotic processes in all kinds of cells regardless of they are normal functioning or cancerogenous. now the question remains what now? Whether chemo and/or Radiotherapy are necessary to halt cancerogenous processes needed further blind retrospective and/or epidemiological follow up studies [1-5]. As a Hematologist when I look at side effects of cancer treatments, which are caused by Oncologists and Radiologists, One might debates with all companies and persons who make profit from such practices that there are no other business to make income other than manipulating health and diseases of cancer patients and their families. As already known for years cancerogenous processes do not kill any subjects by itself. Tumor by definition is a balloon forming swelling and growth of cell membranes physically which changes temporarily proteins/

lipids function locally. When this swelling becomes chronic and being convoyed by pain and increased permeability, and/or loss of function in the vital organs might Intensive care treatments of affected person is highly desired.

Though, from all evidence-based recent data become obvious that it does not mean that affected cancer patient directly supposed to get full treatments of chemotherapies and/or radiotherapies, which exacerbates undesirable side effects toward uncontrolled thrombocytopenia (significant decreased platelets counts) and septic shocks due to suppressed immune system and increased risks of infections, however. Platelets during aforementioned standard cancer therapies might show either hyperactivity and overexpression of their procoagulation function that results in thrombosis, or hypoactivity and loss of functions, which results in severe bleeding disorders, chronically. One might expect more honest medical and Scientific management of wild usage of unnecessary chemo- and radiotherapies in cancer patients wherever would be possible. Taken together, in the 21th Century our call is to serve patients objectively based on Sciencebased economy and not Economy-based Sciences and service. Take home message might be implementation of these recommendations, either toward relevant Physicians who might reduce potential harm to patients and increase the value of health care, and also toward the Regulatory Affairs Managers and organizations, who are approving such (un-)known practices. 


\section{References}

1. Bhella S, Majhail NS, Betcher J, Costa LJ, Daly A, et al. (2008) Choosing Wisely BMT: American Society for Blood and Marrow Transplantation and Canadian Blood and Marrow Transplant Group's List of 5 Tests and Treatments to Question in Blood and Marrow Transplantation. Biol Blood Marrow Transplant 24(5): 909-913.

2. Winocur G, Johnston I, Castel H (2018) Chemotherapy and cognition International cognition and cancer task force recommendations for harmonizing preclinical research. Cancer Treat Rev 69: 72-83.

\section{ISSN: 2574-1241}

DOI: 10.26717/BJSTR.2019.17.003078

Bahram Alamdary Badlou. Biomed J Sci \& Tech Res

(C) $(9)$ This work is licensed under Creative Commons Attribution 4.0 License

Submission Link: https://biomedres.us/submit-manuscript.php
3. Hillis CM1, Schimmer AD, Couban S, Crowther MA (2015) The Canadian Choosing Wisely campaign: the Canadian Hematology Society's top five tests and treatments. Ann Hematol 94(4): 541-545.

4. (2016)Dutch study 5 Hospitals Book entitled' Zorg for Uitkomst, uitkomstindicatoren behandeling kanker. resultaten Santeon Ziekenhuis $20163: 18-20$

5. Platz EA (2017) Reducing Cancer Burden in the Population: An Overview of Epidemiologic Evidence to Support Policies, Systems, and Environmental Changes. Epidemiol Rev 39(1):1-10.

$\begin{array}{ll}\text { BIOMEDICAL } & \text { Assets of Publishing with us } \\ \text { RESEARCHES } & \text { - Global archiving of articles } \\ & \text { - Immediate, unrestricted online access } \\ & \text { - Rigorous Peer Review Process } \\ \end{array}$

